\title{
LEVEL OF DEVELOPMENT OF ELECTRONIC SERVICES IN POLAND COMPARED WITH THE EUROPEAN UNION STATES
}

\author{
JoANNA DOMINIAK \\ Adam Mickiewicz University, Institute of Socio-Economic Geography and Spatial Management, Poznań, \\ Poland
}

Manuscript received January 25, 2011

Revised version March 14, 2011

DominiaK J., Level of development of electronic services in Poland compared with the European Union states. Quaestiones Geographicae 30(2), Bogucki Wydawnictwo Naukowe, Poznań 2011, pp. 57-70, 3 figs, 6 tables. DOI 10.2478/v10117-011-0018-9, ISBN 978-83-62662-62-3, ISSN 0137-477X.

ABSTRACT: The development of information and telecommunications technology has been a breakthrough in the economy and social life. Both modern and traditional sectors of the economy rely on ICT to manufacture new or much improved products and to modify and improve various types of services, e.g. educational, financial, medical, or administrative. With the propagation of ICT there have appeared new ways of acquiring information, learning, doing shopping, or spending leisure time. Thus, progress in ICT contributes to the formation of a knowledge-based economy and an information society.

The chief aim of this article is to analyse the level of development of electronic services in Poland against the backcloth of other European Union states. The following issues will be discussed in more detail: (1) the state of physical infrastructure necessary for the development of e-services in Poland and other EU states, (2) the level of development of selected types of e-services for individual consumers and enterprises in Poland, and (3) a comparison of the level of development of selected types of e-services with other EU states.

KEY wORDS: e-services, e-government, e-commerce, e-learning, European Union

Joanna Dominiak, Institute of Socio-Economic Geography and Spatial Management, Adam Mickiewicz University, ul. Dzięgielowa 27, 61-680 Poznań, Poland; e-mail:dominiak@amu.edu.pl

\section{Introduction}

The political, social and economic changes initiated in Poland in 1989 provided a basis for dynamic development of service activity. The 1990s showed a rapid increase in employment in services. Over the years 1990-2009 the proportion of people working in this sector grew from $37 \%$ to $56 \%$. There was also an increase in the contribution of the service sector to gross value added: in 2008 it generated $65 \%$ of national income, as against $54 \%$ in 1990 . The development of the service sector varied regionally; its high dynamics was recorded in voivodeships with large urban agglomerations: Mazovia, Wielkopolska and Małopolska.

In socio-economic development, the chief factor of service development was an increase in the demand for manufacturing and consumer services. Industrial enterprises started to need more and more specialised and modern services relying on advanced technologies, both own-generated and purchased. There developed services creating the so-called business environment, mostly 
in the computer and financial sectors. The rising level of living of the population brought about a higher demand for consumer services: commercial, medical, educational and tourist.

The service sector contributes to the socioeconomic development of a country and regions through the creation of new jobs, an increase in income, and satisfaction of the population's needs (Illeris 1996). According to Flejterski et al. (2005), four stages can be distinguished in the development of the service sector: (1) an initial stage characterised by the domination of services requiring no great skills, (2) a growth stage involving the development of services requiring some skills, (3) a stage of the service of industry and an increase in the consumption of services, and (4) a stage of the development of services based on high technology. Poland is going through the third stage of service development at present, although there are symptoms of development of high-tech services characteristic of the fourth stage, e.g. services delivered through an electronic medium.

Service development that has been taking place in Poland since the start of 1990s is accompanied by changes in the structure of the service sector and in the organisation of service activity (Nicholls 2001, Rosa 2005).

Changes in the structure of the service sector involve changes in the proportions of individual kinds of service in total services. Increasingly important are specialised services requiring highly skilled workers, including knowledge-intensive services and those offered to producers and business. Their development is a fairly recent phenomenon, hence they are often described as new services. Their increase assumes great significance in terms of the knowledge-based economy (KBE).

Important organisational changes also include the externalisation of service provision and the use of outsourcing to minimise the costs of enterprise operation. An important aspect of this type of change in services is also the appearance of new forms of the provision of traditional services using computer techniques and the Internet (e-services), e.g. e-administration, distance education or e-commerce. Their development has been made possible by advances in information and telecommunications technology (ICT).

\section{Development of information and telecommunications technology (ICT)}

The development of ICT has been a breakthrough in the economy and social life. Its impact on the economy is manifested by a close relationship between ICT development and the formation of the knowledge-based economy. According to Castells (2000: 78), "New information technologies, by transforming the process of information processing, act upon all domains of human activity, and make it possible to establish endless connections between different domains, as well as between elements and agents of such activities. A networked, deeply interdependent economy emerges that becomes increasingly able to apply its progress in technology, knowledge, and management to technology, knowledge, and management themselves." The new manufacturing and service sectors of the economy classed as KBE rely on information and telecommunications technology. ICT makes it possible, also in the traditional industries, to manufacture new or greatly improved products, and with reference to services, it helps to modify and improve the efficiency of various types of services, e.g. educational, financial, medical and administrative.

The development of information and telecommunications technology also leads to fundamental changes in the life of societies. With the popularisation of ICT there have appeared new possibilities of acquiring information as well as learning, working, shopping, or spending leisure time. Progress in ICT contributes to the creation of an information society.

According to Castells (2000: 21), information society is "a specific form of social organisation in which information generation, processing and transmission are transformed into the fundamental sources of productivity and power, due to the new technological conditions". In Polish literature Walczak (2001: 12) defines information society in the following way: "A society that we can call information society is one featuring such a level of information and communications technology as well as programming tools that create technical, economic, educational and other conditions for widespread use of information in the production of goods and delivery of services, and that ensure citizens ready access to information 
technologies and the skill to employ them in their occupational and social activity in order to enrich and update their body of knowledge, make use of cultural facilities, protect their health, spend leisure time, and in several other services enhancing the quality of life". According to Werner (2004), three stages can be distinguished in the development of information society: (1) the first involves the development of basic infrastructure, (2) the second is a period of the popularisation of information and means with a great contribution from society, and (3) the third is a state in which most computers are connected in a network, and communication processes involve the entire society.

The changes produced by the dynamic development of information and telecommunications technology have affected services to a great extent; it has contributed to the rise of e-services. The use of ICT in services has practically changed them in each domain. The popularisation of the Internet has greatly transformed commercial services. The appearance of new distribution paths offered by the Internet helps markets to expand and allows a radical reduction in the cost of economic activity. The Internet plays a significant role in banking and insurance as well as consultancy, book-keeping, and other business services. The development of ICT has also transformed education and administration. What gave an impulse to distance learning were multimedia and interactive techniques of accessing information resources of the Internet. The same tools and technologies allow automation of routine procedures in the public administration field without personal contact between the office worker and the customer being necessary (Werner 2004). The Internet also plays an increasing role in medicine by giving people access to information and making distance diagnosing and medical consultation possible.

The popularisation of the Internet in various domains of the economy and social life, including services, depends on: (1) the existence of the necessary physical infrastructure (hardware and technology), (2) knowledge and suitable skills of society, and (3) the level of income of society. The term 'physical infrastructure' covers not only the equipment of enterprises and households with computer hardware, but also suitable software and instruments allowing Internet access. Of significant importance are also the skills of household members and persons using computers at work. In the case of households, a condition of Internet use is also an appropriate level of income. The cost of Internet access is still a barrier to the growth of e-services in Poland.

The development of e-services is a process in which technological, economic and social spheres tend to interact. There is a close relationship between progress in e-services and the emergence of information society and the knowledge-based economy, which is presented diagrammatically in Fig. 1.

The relations between e-services and information society are of a feedback type. The development and popularisation of e-services enhances the development of information society, and the development of information society stimulates further advances of e-services in the economy and social life. In the economy, e-services are of crucial importance for the formation of KBE. "The knowledge-based economy is a type of economy whose growth and transformation is predominantly controlled by science, or scientific knowledge, which considerably outweighs other factors" (Chojnicki \& Czyż 2006: 18). A special role in $\mathrm{KBE}$ formation is assigned to information and telecommunications technology. Through the development of ICT, the KBE sector leads to the development and popularisation of e-services, and the development of those services stimulates further growth of KBE, e.g. by generating a demand for new equipment, software, and access to information.

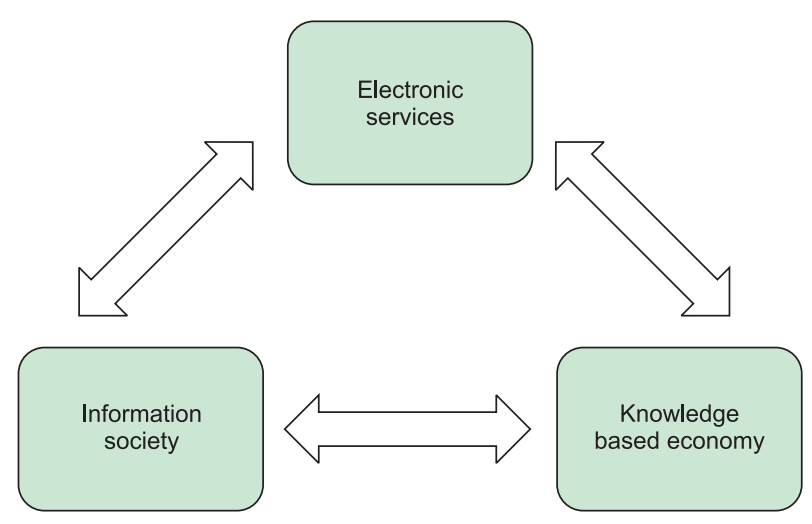

Fig. 1. Relations between electronic services, information society, and the knowledge-based economy. Source: own compilation. 
The use of ICT in services brings benefits to both firms and individual consumers. E-services make it possible to expand markets and lower the costs of economic activity, which leads to higher profits. The benefits to individual consumers, in turn, involve better access to services and products, a greater choice of both, access to information, and time saving. Many of those benefits are qualitative in nature, e.g. improvement in service, customer's comfort, or ready access to information (cf. Goliński 2001).

The chief aim of the article is to analyse the level of development of e-services in Poland as compared with the other European Union states. The following issues will be addressed in particular: (1) the level of physical infrastructure necessary for the development of e-services in Poland and other EU states, (2) the level of development of selected types of e-services for individual consumers and enterprises in Poland, and (3) a comparison of the level of the development of selected types of e-services with the other EU states.

The period under analysis covers the years 2004-2009. The chief material employed was that of the Central Statistical Office (GUS) from its reports Use of information and telecommunications technology concerning enterprises and households. Those were surveys conducted on a representative sample of about 6 thous. enterprises in 2004 and 15 thous. in 2009 (employing more than 9 persons), and 4 thous. households in 2004 and 8 thous. in 2009. The data quoted in the article also come from a report E-Business in Poland by the Institute of Logistics and Warehousing in Poznań, and a Capgemini Poland report on the development of e-government in Poland presenting the results of an analysis of websites of the country's public administration offices.

\section{Characteristics and classification of e-services}

E-services are services provided with the help of information and telecommunications technology employing such facilities as the computer, the cellular phone, and the Internet. In Poland, the Electronically Mediated Service Provision Act defines it as "the provision of a service through teleinformation systems at an individual request of a service recipient, without the simultaneous presence of the parties concerned" (Law Gazette no. 1444/2002, position 1204). Thus, under the Act, an electronic service is a new form of provision of a traditional service involving the use of the Internet and ICT instruments. Electronic technology makes possible service delivery without a need for direct contact between the service provider and the client, which leads to a significant limitation of the role of geographical distance in this field.

E-services are usually classified (1) by recipient and (2) by the kind of service provided. By the first criterion, e-services can be divided into those for enterprises and those for individual consumers. By the other criterion, the following e-services are distinguished:

- electronic administration (e-government) - the provision of services for citizens and business people and the distribution of public information on the Internet, through distance access to all kinds of legal acts and information, e.g. on invitations to tender and investments being implemented, and through an electronic exchange of correspondence;

- electronic trade (e-commerce) - the sale and purchase of goods and services on the Internet, transfer of orders and confirmations as well as the settlement of non-cash payments; the most popular form of e-commerce is Internet shops;

- distance learning (e-learning) - a modern form of education employing information technologies: learning at a distance with the use of computer techniques and the Internet, and supporting didactics with the help of computers and the Internet; it allows having tutorials, taking training courses, or completing studies, and supports the traditional teaching process;

- medical services at a distance (e-health) a field embracing health prophylaxis as well as services improving access to health care, its quality and efficiency;

- electronic banking (e-banking) - a service offered by banks that allows the client access to his account via a computer and a telecommunications connection. Depending on the bank and the software employed, it can only allow checking the state of the account and obtain- 
ing general information about the bank's services, or also performing operations like transfers and making investments;

- electronic marketing (e-marketing) - the use of the Internet to promote products or services via such forms of communication as email messages, banner ads, promotional web pages, electronic bulletins, and other; and

- other kinds of services: electronic insurance, electronic book-keeping, etc.

\section{Access to electronic infrastructure in Poland compared with other European Union states}

The development of e-services depends first and foremost on the accessibility of computers and the Internet. Hence the analysis proper of their level in Poland is preceded by a discussion of access to computer hardware and the Internet as well as kinds of connection used for this purpose, and a description of barriers to the development of e-services with reference to: (a) households, and (b) enterprises. Then Poland is compared with other countries of the European Union.

\subsection{Households}

In $2009,66 \%$ of all the households in Poland had a personal computer, with the proportion being much higher in town $(71 \%$ in cities with more than 100 thous. inhabitants and $66 \%$ in those of under 100 thous.) than in the country (60\%). Possession of a computer varied depending on the household income. They could be found much more often in households with children up to 16 years of age $(91 \%)$. In comparison with 2004, the proportion of computer-equipped households jumped from $36 \%$ to $66 \%$ (Table 1 ).

In 2009, 59\% of households had access to the Internet, of which $51 \%$ joined it using a broadband connection, while an analogue connection was employed by a mere $7 \%$ of users. Almost one-third $(31 \%)$ of broadband connections relied on a DSL link; $18 \%$, on a fixed-line wired connection (e.g. cable television, optical fibres, a LAN network); $8 \%$, on a fixed-line wireless connection
Table 1. Access to computers and the Internet in households (\% of households) in the years 2004-2009.

\begin{tabular}{|l|c|c|c|c|}
\hline \multirow{2}{*}{} & \multicolumn{2}{|c|}{ Computers } & \multicolumn{2}{c|}{ Internet } \\
\cline { 2 - 5 } & $\mathbf{2 0 0 4}$ & $\mathbf{2 0 0 9}$ & $\mathbf{2 0 0 4}$ & $\mathbf{2 0 0 9}$ \\
\hline Total & 36 & 66 & 26 & 59 \\
\hline $\begin{array}{l}\text { Towns with more than } 100 \\
\text { thous. population }\end{array}$ & 44 & 71 & 34 & 65 \\
\hline $\begin{array}{l}\text { Towns with under } 100 \\
\text { thous. population }\end{array}$ & 39 & 66 & 28 & 60 \\
\hline Rural areas & 25 & 60 & 15 & 50 \\
\hline
\end{tabular}

Source: Use of information and telecommunications technology in 2009, GUS, Warszawa.

Table 2. Kinds of connection to the Internet in 2009, by household location and income.

\begin{tabular}{|c|c|c|}
\hline \multirow{2}{*}{} & \multicolumn{2}{|c|}{$\begin{array}{c}\text { Proportion of households ac- } \\
\text { cessing the Internet via }\end{array}$} \\
\cline { 2 - 3 } & $\begin{array}{c}\text { analogue } \\
\text { modem } \mathbf{( \% )}\end{array}$ & $\begin{array}{c}\text { broadband } \\
\text { connection } \\
\text { (\%) }\end{array}$ \\
\hline Total & 6.9 & 51.1 \\
\hline town & 6.7 & 56.3 \\
\hline countryside & 7.3 & 40.6 \\
\hline Net monthly income: & & \\
\hline under 1,428 zlotys & 3.6 & 7.4 \\
\hline 1,429 to 2,158 zlotys & 6.7 & 17.0 \\
\hline 2,159 to 3,351 zlotys & 7.8 & 25.8 \\
\hline over 3,351 zlotys & 9.3 & 38.5 \\
\hline
\end{tabular}

Source: Use of information and telecommunications technology in 2009, GUS Warszawa.

(radio or satellite); and 7\%, on a mobile connection in a cellular telephony network. Broadband access was more frequent in big cities (61\%) than in the country (41\%) (Table 2). Most connections to the Internet were mostly made via a stationary computer $(45 \%)$. The proportion of households relying on mobile facilities was $31.5 \%$, of which $22 \%$ used a laptop and $16 \%$ a cellular phone.

Between 2004 and 2009, the proportion of computer users grew from $23 \%$ to $42 \%$. Those running a computer regularly (at least once a week) constituted $55 \%$, while $42 \%$ used it daily or almost daily. There was also an increase in the proportion of Internet users. Over the years 2004-2009 the proportion of persons surfing the Internet on a daily basis grew from $12 \%$ to $39 \%$, and of onceweekly visitors, from $22 \%$ to $52 \%$ (Table 3 ).

Persons using the Internet for private purposes did so primarily to communicate $(50 \%)$ and seek information and on-line servers (49\%), usually about goods and services (29\%) and healthrelated issues $(22 \%)$. Almost one in three users 
Table 3. Proportion of computer and Internet users in 2004 and 2009, by frequency of use.

\begin{tabular}{|l|c|c|c|c|}
\hline \multirow{2}{*}{ Frequency of use } & \multicolumn{2}{|c|}{$\begin{array}{c}\text { Proportion of } \\
\text { computer users } \\
\text { (\%) }\end{array}$} & \multicolumn{2}{|c|}{$\begin{array}{c}\text { Proportion of } \\
\text { Internet users } \\
\text { (\%) }\end{array}$} \\
\cline { 2 - 5 } & $\mathbf{2 0 0 4}$ & $\mathbf{2 0 0 9}$ & $\mathbf{2 0 0 4}$ & $\mathbf{2 0 0 5}$ \\
\hline $\begin{array}{l}\text { Daily or almost } \\
\text { daily }\end{array}$ & 23 & 42 & 12 & 39 \\
\hline $\begin{array}{l}\text { Regularly, at least } \\
\text { once a week }\end{array}$ & 35 & 55 & 22 & 52 \\
\hline $\begin{array}{l}\text { Over the last three } \\
\text { months }\end{array}$ & 40 & 59 & 29 & 56 \\
\hline
\end{tabular}

Source: Use of information and telecommunications technology in 2009, GUS Warszawa.

connected to the Internet for educational purposes, and $21 \%$ to make use of banking services. Also popular was reading and downloading on-line journals as well as playing music and games.

Among the chief reasons given for having no access to the Internet were 'no such need' (20\%) and too high costs of the hardware (12\%) and Internet access itself $(9 \%)^{1}$. Also listed was lack of suitable skills $(12 \%)$.

Internet use in Poland was compared with other European Union states. In 2009 the proportion of EU households with Internet access amounted to $65 \%$; the figure in Poland was lower $(59 \%)$. Still, it was higher than in many other states of
East-Central and Southern Europe, like Bulgaria (30\%), Romania, Greece, Portugal, Italy, Spain, Cyprus (38-53\%), as well as the Czech Republic $(54 \%)$ and Hungary (55\%). The highest proportion of households with access to the Internet was recorded in The Netherlands, Luxembourg, Denmark and Sweden (83-90\%) (Fig. 2).

Apart from access to physical infrastructure, a big role in the development of e-services is also played by the population's computer skills. According to a 2009 research by the Central Statistical Office (GUS), more than $70 \%$ of Poland's inhabitants aged 16-74 were able to copy or move a file or folder. A bit lower percentage (64\%) could copy and paste fragments of texts. About $46 \%$ of computer users could install new hardware and employ basic mathematical functions in a spreadsheet. More than one-third could solve problems related to computer work and compress files with the help of a special program. The skills of Poles in program writing looked much worse $(9 \%)$. As to the Internet, most Poles declared the skill to use a search engine (94\%) and send e-mail messages with attachments (71\%). Almost $40 \%$ could phone via the Internet and take part in chats and discussion groups. One in three Internet-using Poles could also download and install software

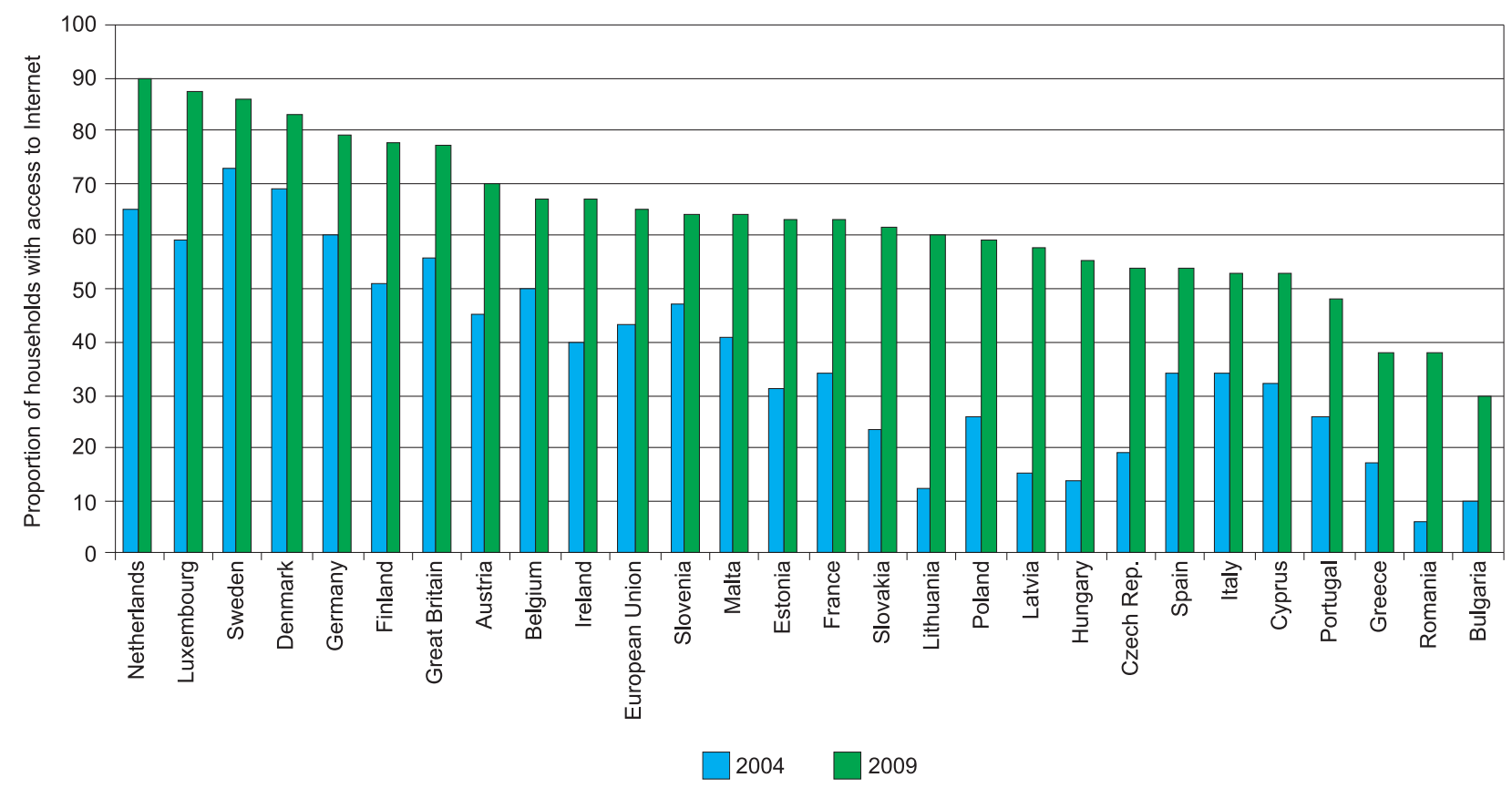

Fig. 2. Proportion of households with Internet access in the European Union countries in the years 2004-2009. Source: own compilation.

1 It was possible to choose more than one answer. 
and secure their computers against viruses. The skill to create web pages was poor $(11 \%)$. However, according to GUS, the computer skills of Poles keep improving. A rapid increase can be observed in both, elementary skills like the use of basic programs, and more advanced operations requiring some computer knowledge and experience (creating web pages, writing programs).

\subsection{Enterprises}

In $2009,93 \%$ of the enterprises under study used computers and $90 \%$ had access to the Internet. The figures varied depending on the size of firms and their line of activity. Almost all those employing more than 250 workers had computers and Internet access, while in medium-sized ones (employing from 50 to 249 persons) the respective proportions were $98 \%$ and $97.7 \%$, and in small ones, $91 \%$ and $88 \%$.

By line of activity, there was a high proportion of enterprises equipped with computers and the Internet in the PKD (Polish Classification of Economic Activities) sections of Real estate activities as well as Scientific, technical and professional activities (apart from IT firms, all of which had computers with Internet access). The figures were the lowest among hotels and other accommodation and eating facilities, as well as among construction firms (Table 4).

Among big enterprises with access to the Internet, as many as $94 \%$ had a broadband connection. This proportion was much lower in small and medium-sized firms (Table 5). In 2009 there were $41 \%$ of workers using a computer at least once a week, with $34 \%$ having a computer with Internet access.

In 2009 the proportion of enterprises with access to the Internet was lower in Poland (90\%) than the EU mean (94\%). Over the years 20042009, the proportion of such enterprises in some EU states had changed significantly. In the least advanced states - Romania and Bulgaria ${ }^{2}$ - an increase was recorded from 52 to $73 \%$ and from 62 to $84 \%$, respectively. There was also a group of states in which this proportion grew from about $80 \%$ in 2004 to more than $90 \%$ in 2009 (the

\footnotetext{
2 Bulgaria and Romania joined the EU in 2007.
}

Table 4. Proportion of enterprises equipped with computers and Internet access in 2009, by line of activity.

\begin{tabular}{|l|c|c|}
\hline \multicolumn{1}{|c|}{ Line of activity } & $\begin{array}{c}\text { Proportion } \\
\text { of enter- } \\
\text { prises using } \\
\text { computers } \\
\text { (\%) }\end{array}$ & $\begin{array}{c}\text { Proportion } \\
\text { of enter- } \\
\text { prises with } \\
\text { Internet } \\
\text { access (\%) }\end{array}$ \\
\hline Total & 92.6 & 90.1 \\
\hline \multicolumn{1}{|c|}{ small } & 91.3 & 88.2 \\
\hline medium-sized & 98.0 & 97.7 \\
\hline big & 99.7 & 99.6 \\
\hline Manufacturing & 92.4 & 89.5 \\
\hline $\begin{array}{l}\text { Manufacture and supply } \\
\text { of electricity and gas }\end{array}$ & 97.0 & 97.0 \\
\hline Construction & 90.9 & 88.8 \\
\hline Trade and repairs & 93.8 & 91.0 \\
\hline Transporting and storage & 91.9 & 90.1 \\
\hline $\begin{array}{l}\text { Accommodation and food } \\
\text { service activities }\end{array}$ & 79.8 & 74.8 \\
\hline $\begin{array}{l}\text { Information and commu- } \\
\text { nication }\end{array}$ & 96.4 & 95.8 \\
\hline $\begin{array}{l}\text { Financial and insurance } \\
\text { activities }\end{array}$ & 99.2 & 98.8 \\
\hline Real estate activities & 98.9 & 98.3 \\
\hline $\begin{array}{l}\text { Scientific and technical } \\
\text { activities }\end{array}$ & 98.5 & 97.4 \\
\hline $\begin{array}{l}\text { Administrative and sup- } \\
\text { port service activities }\end{array}$ & 89.2 & 88.9 \\
\hline
\end{tabular}

Source: Use of information and telecommunications technology in 2009, GUS Warszawa.

Czech Republic, Ireland, Spain, France, Italy, The Netherlands, Poland). In the group of states at the highest level of socio-economic development (e.g. Belgium, Denmark, Germany, Finland, Austria, Sweden, Great Britain) no significant changes in the index value (ca. 96\%) were observed in the study period.

Table 5. Proportion of enterprises with Internet access in 2009, by size.

\begin{tabular}{|c|c|c|}
\hline \multirow{2}{*}{ Enterprises by size } & \multicolumn{2}{|c|}{$\begin{array}{c}\text { Proportion of enterprises } \\
\text { accessing the Internet via }\end{array}$} \\
\cline { 2 - 3 } & $\begin{array}{c}\text { analogue } \\
\text { modem } \mathbf{( \% )}\end{array}$ & $\begin{array}{c}\text { broadband } \\
\text { connection } \\
\mathbf{( \% )}\end{array}$ \\
\hline Total & 40.5 & 58.1 \\
\hline small & 41.5 & 52.9 \\
\hline medium-sized & 36.1 & 77.1 \\
\hline big & 37.4 & 94.0 \\
\hline
\end{tabular}

Source: Use of information and telecommunications technology in 2009, GUS Warszawa. 


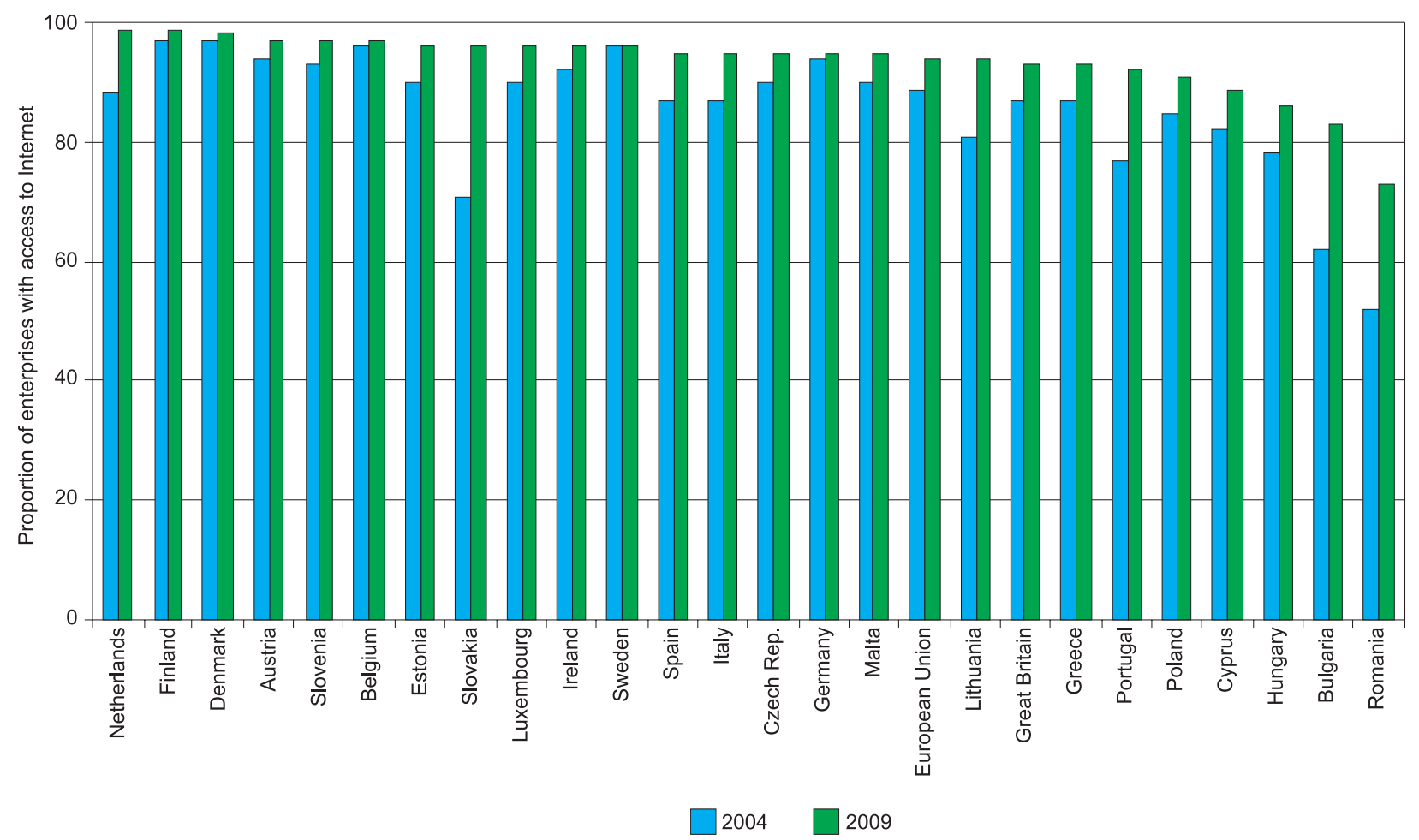

Fig. 3. Proportion of enterprises with Internet access in the European Union countries in the years 2004-2009. Source: own compilation.

\section{Level of development of e-services in Poland}

The level of development of e-services in Poland was analysed on the example of their four types: e-government, e-commerce, e-learning, and e-health services. The individual types of eservices are discussed divided into two categories: (1) those for households and (2) those for enterprises.

\subsection{E-government services}

"In the emerging new electronic economy, administration cannot work in the old way" (Cellary 2002: 94). Services provided so far in traditional ways (e.g. issuing decisions and permits, keeping register) are being replaced with Internet- and ICT-mediated e-services. All kinds of documents, forms, applications or announcements can be substituted with their digital counterparts: web pages with appropriate information, electronic forms, e-mail correspondence, and documents authorised by an electronic signature (cf. Kaczmarek 2005). The introduction of e-government services is a considerable convenience for both the citizens and office workers, their basic asset being the fact that they save time of both sides.

There are four ways of making use of public services on the Internet, which are simultaneously stages in the development of e-government:

(1) a possibility of finding information about the given office and the services it offers on its Internet site,

(2) a possibility of finding the information and downloading forms from the website,

(3) a possibility of finding the information, downloading forms, filling them in and sending back via the Internet, and

(4) a possibility of performing all the activities necessary to settle a given official matter through electronic channels, from obtaining information to making the required payments and obtaining the document applied for. 
A decided development of the informatisation of offices in Poland occurred at the start of 2002, when the Access to Public Information Act had come into effect. Another acceleration of the development of e-government services, in 2003, was connected with their adjustment to the European Union standards. It followed the guidelines of the eEurope 2005 Action Plan laying down the framework for the construction of information society in the European states. As part of the implementation of this strategy, a government project "The Gate to Poland" was adopted that sought to accommodate EU recommendations.

The level of development of e-government in Poland differed in the particular communes. Most offices only offered services in the form of a presentation of ordered information on their websites. Some offices made it possible to download suitable forms, and only a few offered the possibility of sending them back after filling. None of the public administration institutions had introduced electronic payments.

According to the GUS survey of 2009, in Poland the proportion of persons who contacted public administration via the Internet amounted to $27 \%$. Their chief aim was to obtain information on the offices' websites (25\%) and to download official forms (19\%). Sending back filled forms was only declared by $10 \%$ of Poles. In comparison with 2005, progress in e-government services was considerable. In that year only $11 \%$ of Polish residents sought information, only $6 \%$ downloaded appropriate forms over the Internet, and only $3 \%$ took the possibility of sending them back through electronic channels.

In 2009 the proportion of enterprises using the Internet in their contacts with public administration to obtain necessary information amounted to $77 \%$, a significantly higher figure than in 2004 $(57 \%)$. Those visiting public administration websites to retrieve various forms (e.g. tax forms) constituted $80 \%$, and those using the Internet to send back filled forms, $89 \%$.

\subsection{E-commerce}

E-commerce is one of the fasted developing types of electronic services. For the buyer, the most essential advantage of e-commerce is the possibility of shopping at any hour and from any place, without the need to leave home. Another advantage is wider access to global markets and an unlimited choice of goods from all the world. Of no little importance is also the usually lower price of goods (not inflated by the costs of distribution, hiring selling space, etc.).

In the recent years the development of this line of e-services in Poland has been highly dynamic. According to estimates, in 1996 there were about 30 Internet shops there, in 2005 the figure jumped to about 800, and in 2008 reached 7.5 thousand.

Nearly three-fourths of the shops operated only in the Internet, the rest were an additional activity of traditional commercial firms. More than a half of Internet shops had only two years' experience. Those existing for 5-10 years accounted for a mere $16 \%$ of the total, and only one in ten operated for more than 10 years.

In 2009 the total worth of goods and services ordered / bought over the Internet amounted to 5.2 billion zlotys. By comparison, in 2004 Polish residents shopped over the Internet for a total of 360 million zlotys. During the year preceding the GUS survey, 30\% of Internet-using respondents ordered goods or services for their private use, as against a mere $14 \%$ in 2004 .

The structure of goods ordered on the Internet in Poland is diversified. In 2009 the most frequently bought articles were computers and computer accessories, telephones, radio and TV sets, domestic appliances, computer games and programs, as well as cosmetics and pharmaceuticals.

The main factors stimulating the development of e-commerce, in the opinion of Internet shop owners, was a search for new groups of clients and the wish to keep up with the competition. On-line trade is gradually becoming a channel of goods distribution paralleling the traditional sale (Elektroniczna gospodarka ... 2004).

The chief barrier to the development of e-commerce in Poland is people's distrust of Internet shops $(70 \%)$. A significant retarding factor is also poor telecommunications infrastructure: $67 \%$ of the respondents gave lack of access as a reason for not shopping over the Internet. Listed among other barriers were no direct contact with the product $(57 \%)$ and the seller (33\%), and fear for 
the security of electronic payment (Księżopolski \& Kotulski 2004).

In 2009, over three months preceding the GUS survey, $18 \%$ of Poles shopped for products and services on the Internet, while this proportion amounted to $23 \%$ for the year preceding the study. The percentage of enterprises shopping over the Internet was $17 \%$, with big firms accounting for the largest proportion, $29 \%$, while medium-sized ones contributed $17 \%$, and small ones, $10 \%$.

\subsection{E-learning}

E-learning is an important element of the modern education system. It is mostly addressed to persons seeking to raise their level of education and professional skills, the unemployed, young people from poor families and rural areas with poor access to knowledge, and disabled persons.

The rapid progress in technology generates the need for constant revision and deepening of one's knowledge. Distance learning (or e-learning), understood as a method of conducting the didactic process when the teacher is separated from the pupil, plays an ever greater role in the process of lifelong learning (ePolska ... 2001).

The chief advantages of e-learning are: elimination of costs, saving time, the possibility of participating in courses conducted by teachers from all over the world, and no limits to the number of course members. A very important asset of elearning is a free choice of time for classes and their duration. Drawbacks include the need for self-discipline and strong motivation, as well as lack of direct contact with the instructor.

Distance learning takes two chief directions: (1) regular higher studies, complementary master's studies and licentiate studies; and (2) tutorials and training courses, e.g. vocational. In Poland there are many offers of on-line study, e.g. at the Warsaw Polytechnic (Extramural Engineering Studies in the e-learning centre OKNO), Marie Curie-Skłodowska University in Lublin, the Higher School of Humanities and Economics in Łódź (as part of the Polish Virtual University), and the Łódź University (the PAM Center). Even broader is the offer of complementary master's studies and postgraduate studies as well as all kinds of on-line tutorials and training courses.
There also appear secondary schools offering an Internet form of instruction. This form of education is largely addressed to economically active, ill, and disabled persons.

In 2009 the proportion of persons who used the Internet (in three months preceding the survey) for training and educational purposes amounted to $32 \%$, with $30 \%$ using the Internet to upgrade their body of knowledge, 13\% seeking information about education or training offers, and only $1 \%$ actually taking part in on-line training.

In 2009 the Internet was used for educational purposes by $25 \%$ of all enterprises. Usually it was big enterprises that engaged in e-learning, at $46 \%$, while medium-sized ones constituted $34 \%$ and small firms only $23 \%$. The greatest proportion of firms making use of e-learning could be found in the insurance and R\&D sectors. For training purposes the Internet was used by more than $50 \%$ of firms of those sectors, twice the mean for all the enterprises.

\subsection{E-health}

Medical electronic (e-health) services are the poorest developed form of e-services in Poland. Modern teleinformation technologies find application in a variety of medicine-related services. They include distance diagnosis, on-line medical consultations, electronic information services, and keeping electronic patient files.

Modern ICT technology makes it possible to accelerate and improve the diagnostic stage considerably. The Internet allows a rapid exchange of information between patient and physician and among health care facilities at a variety of levels. With the help of telecommunications connections it is possible to send a complete set of test results and transmit radiological images, which in turn allows multilateral medical consultations including specialised centres throughout the world without the need to transport the patient. Telediagnostics also involves examining, monitoring or controlling the state of the patient's health at a distance owing to specialised Internet portals (e.g. www.telezdrowie.pl, a telemedical diagnostic-rehabilitation system which allows diagnosing vision, hearing and speech defects; or www. kardiotel.pl, a cardiological monitoring centre). 
Besides, it is also possible to obtain immediate medical advice and consultation via the Internet and its special portals with physicians on duty.

The special Internet portals offering information services in the field of medicine can be intended for patients, physicians or pharmacists (www. poradnikmedyczny.pl; www.zdrowie.med.pl). They supply details of various complaints and diseases as well as their prophylaxis and treatment, and conduct medical consulting. There are also specialised medical portals intended only for persons connected with medicine professionally, e.g. www.eskulap.pl. Their function, apart from information, is also education. A separate group includes all kinds of address bases of medical facilities where patients can check their opening hours and make an appointment.

Information and telecommunications technology is also applied to create, keep and make available the medical documentation of a patient (history of treatment), and to make settlements and pay medical benefits and insurance.

In 2009 the proportion of persons using the Internet to obtain health-related information was $18 \%$, significantly higher than the 2005 figure (7\%).

The latest GUS reports do not provide detailed information about distance medicine. In 2005 the proportion of persons using the Internet to obtain medical advice was a mere $0.4 \%$, and even fewer persons made appointments on-line $(0.1 \%)$. This is due to the fact that at that time there were still few surgeries offering the possibility of distance appointment making. Those that did were largely private surgeries rendering medical services against payment.

\section{Level of development of e-services in Poland and other EU states}

A comparison of the level of development of e-services in the European Union states is made on the basis of indices involving the four types under analysis: e-government, e-commerce, elearning, and e-health services.

\subsection{E-government}

In 2009 the mean proportion of customers in the European Union states using the Internet to obtain information about the activity of an administration office was $27.5 \%, 11$ percentage points higher than in Poland $(16.3 \%)^{3}$. The index differed widely, being the highest in Denmark ${ }^{4}$ (67\%) and Luxembourg, The Netherlands and Sweden (in excess of 50\%), and the lowest in Romania (6\%). EU residents using the Internet to download and send back forms constituted 18\% and $13 \%$, respectively (as against $11.5 \%$ and $5 \%$ in Poland). In comparison with other EU countries, the proportion of Poles resorting to e-government services is still low.

However, the use of the Internet in Poland in enterprise-public administration contacts was close to the European mean. The proportion of enterprises relying on e-government services was $68 \%$, only slightly lower than the mean for all the EU states $(72 \%)^{5}$.

An analysis of indices of e-government services in the European Union leads to the conclusion that administration in the countries of northern Europe, especially Scandinavia, is much more highly informatised than in the Mediterranean ones. This is due not only to differences following from the level of socio-economic development and innovativeness of the economy, but also to cultural factors. According to Krzysztofek (2002: 73), the residents of Nordic countries prefer indirect forms of contact, while southern societies cultivate direct ones.

\subsection{E-commerce}

In 2009 the proportion of persons shopping over the Internet in Poland during three months preceding the survey amounted to $18 \%$, and during the year, to $23 \%$. Both figures were much lower than in the European Union (30\% and 37\%, respectively). The proportion of on-line shoppers was the highest in Great Britain (66\%) and Swe-

3 On the basis of a three-month record of results.

4 High, or even higher, figures were also recorded in such non-EU states as Iceland (75\%) and Norway $(65 \%)$.

5 On the basis of a three-month record of results. 
den, Denmark and The Netherlands (63-64\%), and the lowest - as in the case of e-government services - in the new member states presenting the lowest level of socio-economic development (Romania and Bulgaria, 2-5\%, and Lithuania, $8 \%)$. Relatively low indices were also recorded in the countries of southern Europe: Italy and Portugal $(12 \%-13 \%)$.

As to enterprises, in Poland they shopped online at a much more modest scale than in other EU countries. In 2009 the mean proportion of such firms in the EU states was $24 \%$, as against a mere $12 \%$ in Poland.

\subsection{E-learning}

A comparison of the proportion of persons using the Internet to gain education in Poland and in other EU states leads to the conclusion that this form of instruction is not yet well developed in Poland. In 2006 only $4 \%$ of Poles made use of it, as against $23 \%$ in Finland, 18\% in Great Britain, and $17 \%$ in The Netherlands. While both Polish lecturers and students ever more often resort to new technologies in the teaching process, e-learning still tends to be treated rather as a complementary method of education. But the proportion of enterprises that employed distance learning in the training of their workers amounted to $25 \%$.

\subsection{E-health}

In comparison with other European countries, Poland displayed a low level of development of e-health services. Among e-health indices, the highest figures were recorded in the proportion of persons seeking medical information. This index varied widely among the EU states. In 2009 it was the highest in Luxembourg and Finland (54\%-56\%), while in Poland it only amounted to $18 \%$. As to on-line medical advice, in $2005^{6}$ persons seeking it constituted a mere $0.4 \%$ in Poland, as against the EU mean of $2 \%$. Even fewer people made appointments on-line. In Poland, too, the biggest group included Internet users seeking

Data on e-health services in EU states concerning getting medical advice and arranging visits on-line come from 2005. medical information (7.1\%), although their proportion was again much lower than in West European countries.

\section{Classification of the EU states by the level of development of e-services}

On the scale of development of three categories of e-services (e-government, e-commerce, and e-learning), the EU states were divided into three classes: those showing a high, an average and a low level of their development (2009 data) (Table 6).

The highest level of development of e-services is shown by the richest EU states (as measured by per capita income): Germany, Luxembourg, France, The Netherlands, and the Scandinavian states of Denmark, Finland and Sweden. An average level can be found in both, the 'old' EU members (Austria, Belgium) and those of Central and Eastern Europe that joined the Union in 2004: Estonia, Slovenia and Slovakia. A low level is displayed by two groups of states. One includes the most recent arrivals: Romania and Bulgaria (admitted in 2007), and the Czech Republic, Latvia, Lithuania, Hungary and Poland (admitted in 2004). The other group includes countries of southern Europe: Greece, Portugal, Italy and Cyprus.

\section{Summing up}

Poland entered the path of e-service development with much delay, hence the big differences persisting between this country and those of western and northern Europe. However, over the period under study, 2004-2009, e-services in Poland showed high development dynamics, especially in the fields of e-government and e-commerce. This can be put down to Poland's accession to the European Union. Under the integration process, apart from the inflow of financial means from the Community funds earmarked for the development of physical infrastructure, there was also a rise in the mobility of Poles and the development of social and economic contacts that it brought about. This, in turn, caused a significant increase in the demand for e-services. 
Table 6. Classification of EU states by level of development of e-services.

\begin{tabular}{|c|c|c|c|c|}
\hline \multirow{2}{*}{ State } & \multicolumn{3}{|c|}{ Level of e-service development } & \multirow{2}{*}{$\begin{array}{c}\text { General level of } \\
\text { e-service development }\end{array}$} \\
\hline & e-government & e-commerce & e-learning & \\
\hline Denmark & high & high & average & \multirow{7}{*}{ high } \\
\hline Germany & average & high & high & \\
\hline Luxembourg & high & high & average & \\
\hline Finland & high & high & high & \\
\hline Sweden & high & high & average & \\
\hline France & high & high & * & \\
\hline Netherlands & high & high & high & \\
\hline Ireland & average & average & average & \multirow{7}{*}{ average } \\
\hline Austria & average & high & average & \\
\hline Spain & average & average & low & \\
\hline Belgium & low & low & * & \\
\hline Slovenia & average & average & high & \\
\hline Estonia & high & average & low & \\
\hline Slovakia & average & average & low & \\
\hline Cyprus & low & low & average & \multirow{8}{*}{ low } \\
\hline Lithuania & low & low & average & \\
\hline Greece & low & low & low & \\
\hline Portugal & low & low & low & \\
\hline Italy & low & low & low & \\
\hline Czech Republic & low & average & low & \\
\hline Latvia & low & low & average & \\
\hline Poland & low & average & low & \\
\hline
\end{tabular}

* - no data

Source: own compilation.

\section{References}

CASTELLS M., 2000. The rise of the network society. Blackwell, Oxford (2nd edition).

Cellary W., 2002. Organizacja administracji publicznej na potrzeby obywateli (Citizen-oriented organisation of public administration). In: Cellary W. (ed.), Polska w drodze do globalnego społeczeństwa informacyjnego. Raport o rozwoju społecznym. Program Narodów Zjednoczonych ds. Rozwoju (UNDP), Warszawa: 94-97.

CHojnicki Z. \& CZYŻ T., 2006. Aspekty regionalne gospodarki opartej na wiedzy w Polsce (Regional aspects of the knowledge-based economy in Poland). Bogucki Wydawnictwo Naukowe, Poznań.

eCommerce 2006. Badanie sklepów internetowych (E-commerce 2006. Survey of Internet shops). www.sklepy24.pl.

Elektroniczna gospodarka w Polsce. Raport 2004 (E-business in Poland. Report 2004). Prepared by the Institute of Logistics and Warehousing on commission from the Ministry of Economy. www.e-gospodarka.net.pl.

Elektroniczna gospodarka w Polsce. Raport 2005. (E-business in Poland. Report 2005). Prepared by the Institute of Logistics and Warehousing on commission from the Ministry of Economy. www.e-gospodarka.net.pl.

ePolska - Plan działań na rzecz rozwoju społeczeństwa informacyjnego w Polsce na lata 2001-2006 (ePoland - A plan of measures for the development of information society in Poland for the years 2001-2006). 2001. A government document.
Eurostat 2005. e-Government 2004: Internet based interaction with European business and citizens. Statistics in focus, European Communities.

Flejterski S., Panasiuk A., Perenc J. \& Rosa G. (eds), 2005. Wspótczesna ekonomika ustug (Service economics today). Wydawnictwo Naukowe PWN, Warszawa.

GoLIŃSKI M., 2001. Społeczeństwo informacyjne - problemy definicyjne i problemy pomiaru (Information society: Problems with definition and measurement). In: Haber H.L. (ed.), Polskie doświadczenia w ksztattowaniu społeczeństwa informacyjnego: dylematy cywilizacyjno-kulturowe. Conference materials. Kraków, http:// winntbg.bg.agh. edu.pl/ skrypty/0037/cz0-r11.html.

ILLERIS S., 1996. The service economy: A geographical approach. John Wiley \& Sons. Chichester, New York, Brisbane, Singapore.

KACZMAREK T., 2005. Struktury terytorialno-administracyjne $i$ ich reformy w krajach europejskich (Territorial-administrative structures and their reforms in European states). Wydawnictwo Naukowe UAM, Poznań.

KacZMAReK-ŚLIWIŃSKA M., 2003. Stan e-government w Polsce (State of e-government in Poland). Szkoła Główna Handlowa w Warszawie, www.e-mentor.edu.pl

KRZYSZTOFEK K., 2002. Technologie informacyjne i rozwój cywilizacyjny (Information technologies and progress of civilisation). In: Cellary W. (ed.), Polska w drodze do globalnego społeczeństwa informacyjnego. Raport o rozwoju społecznym. Program Narodów Zjednoczonych ds. Rozwoju (UNDP), Warszawa: 73-74.

KSIĘŻOPOLSKI B. \& KOTULSKI Z., 2004. Zagrożenia procesów komunikacyjnych $\mathrm{w}$ e-commerce oraz sposoby prze- 
ciwdziałania (Threats to communication processes in ecommerce and counteracting measures). In: Kisielnicki J. (ed.), Informatyka narzędziem wspótczesnego zarządzania, PJWSTK, Warszawa: 246-254.

Nicholls R., 2001. Przekształcenia w sektorze usług w Polsce w perspektywie europejskiej. In: Rogoziński K. (ed.), Transformacja w ustugach. Sektor ustug w Polsce w latach 1990-1999. Zeszyty Naukowe AE, Poznań: 11-28.

OleCHNICKA A., 2004. Regiony peryferyjne $w$ gospodarce informacyjnej (Peripheral regions in an information economy). Wydawnictwo Naukowe Scholar, Warszawa.

RosA G., 2005. Struktura i przeobrażenia współczesnego sektora usług (Structure and transformation of the presentday service sector). In: Flejterski S., Panasiuk A., Perenc J. \& Rosa G. (eds), Wspótczesna ekonomika ustug. Wydawnictwo Naukowe PWN, Warszawa: 59-80.

Rozwój eGovernment w Polsce. 3. edycja badań eEurope (Development of e-government in Poland. 3rd edition of the
eEurope survey). Prepared by Capgemini Poland on commission from the Ministry of Science and Informatisation. Warszawa 2004, www.egov.pl.

WALCZAK T., 2001. Społeczeństwo informacyjne a zadania statystyki (Information society and the tasks of statistics). Wydawnictwo Akademii Ekonomicznej w Krakowie, Kraków.

WERNER P., 2004. Geograficzne uwarunkowania rozwoju infrastruktury spoteczeństwa informacyjnego w Polsce (Geographical determinants of the development of information society in Poland). Uniwersytet Warszawski, Warszawa.

Wykorzystanie technologii informacyjno-telekomunikacyjnych $w 2004$ roku (Use of information and telecommunications technology in 2004). GUS, Warszawa, www.stat.gov.pl.

Wykorzystanie technologii informacyjno-telekomunikacyjnych w 2009 roku (Use of information and telecommunications technology in 2009). GUS, Warszawa, www.stat.gov.pl. 